\title{
PRINCÍPIOS DE SEMIOTÉCNICA E DE INTERPRETAÇÃO DO EXAME CLÍNICO DO ABDÔMEN
}

\author{
PRINCIPLES OF SEMIOTECHNIC AND INTERPRETATIONOF \\ THE ABDOMEN CLINICAL EXAMINATION
}

Ulysses G. Meneghelli \& Ana L. C. Martinelli

Docentes. Divisão de Gastroenterologia. Departamento de Clínica Médica. Faculdade de Medicina de Ribeirão Preto - USP.

Correspondência: Ulysses G. Meneghelli. Divisão de Gastroenterologia. Departamento de Clínica Médica.Faculdade de Medicina de Ribeirão Preto -USP. Campus Universitário de Monte Alegre. CEP 14049-900 Ribeirão Preto - SP. Fax (16) 633.6695 e.mail: ugmenegh@fmrp.usp.br

MENEGHELLI UG \& MARTINELLI ALC. Princípios de semiotécnica e de interpretação do exame clínico do abdômen. Medicina, Ribeirão Preto, 37: 267-285, jul./dez 2004.

RESUMO: O propósito desta publicação é o de levar aos alunos de Graduação em Medicina alguns conhecimentos básicos sobre como fazer e como interpretar o exame clínico do abdômen. Para alcançar o objetivo, procurou-se desenvolver os vinte e oito objetivos enunciados pela coordenadoria do Curso de Semiologia Médica do Departamento de Clínica Médica da Faculdade de Medicina de Ribeirão Preto (USP) e que são exigidos dos respectivos alunos, juntamente com a avaliação do desempenho prático. O conteúdo abrange, de forma sumária, os principais tópicos da inspeção, ausculta, palpação e percussão do abdômen.

UNITERMOS: Exame Clínico. Semiologia. Inspeção. Auscultação. Palpação. Percussão. Abdomen.

A descrição que será feita limita-se a trazer elementos para a execução e compreensão dos vinte e oito itens constantes do Roteiro de Objetivos do exame do abdômen do Curso de Semiologia Geral (RCG 314), ministrado pelo Departamento de Clínica Médica da Faculdade de Medicina de Ribeirão Preto (USP), no ano de 2003, aos alunos do terceiro ano médico. Considerando que o curso é muito condensado, dispondo os alunos de restrito tempo para o estudo nos compêndios, procurou-se direcionar o aprendizado da semiologia do abdômen para um conjunto de vinte e oito objetivos bem definidos, que representariam o mínimo necessário para o futuro médico iniciar seu treinamento na ciência e na arte do exame físico desse segmento do corpo humano. Evidentemente, é, apenas, uma base teórica para o indispensável ensino prático, intensivo, ministrado por docente experimentado, e para pequenos grupos de alunos (máximo de sete).
No final, indicam-se algumas obras que serviram de referência para esta apresentação e que podem servir como fonte de informações complementares ao leitor.

Na semiologia do abdômen, são empregados os tradicionais métodos de inspeção, ausculta, palpação e percussão, de preferência na ordem indicada.

\section{OBJETIVOS}

1- Delimitar, a partir dos referenciais adequados, as regiões topográficas da face anterior do abdômen (epigástrio, mesogástrio, hipogástrio, hipocôndrios, flancos, fossas ilíacas e quadrantes superiores e inferiores)

A divisão topográfica do abdômen é necessária para o médico fazer referência acerca da localização e irradiação de dores ou de outros sintomas abdomi- 
nais na descrição da anamnese, bem como para indicar o local dos achados do exame físico do abdômen. Há duas formas clássicas de divisão do abdômen; uma que o divide em nove áreas e outra que o divide em quatro áreas. O clínico pode aplicar a que lhe parecer mais fiel e clara para descrever o sintoma ou o achado do exame físico.

Para a delimitação das nove áreas tradicionais (epigástrio, mesogástrio, hipogástrio, hipocôndrios, flancos, fossas ilíacas), usualmente, são utilizadas três linhas horizontais, duas oblíquas e duas arqueadas, como pode ser observado na Figura 1.

Os elementos anatômicos a serem considerados para a divisão topográfica do abdômen são: a base do apêndice xifóide, as bordas do gradeado costal (ângulo de Sharpy), as extremidades das décimas costelas, as espinhas ilíacas ântero-superiores, os ramos horizontais do púbis e as arcadas inguinais.

A linha horizontal superior tangencia a base do apêndice xifóide, a média une as extremidades das décimas costelas (aproximadamente, no ponto em que as linhas hemiclaviculares, direita e esquerda, cruzamse com as rebordas costais) e a inferior liga as espinhas ilíacas, ântero-superiores.

As linhas oblíquas são quase verticais e vão da extremidade da décima costela até a extremidade do ramo horizontal do púbis, respectivamente à direita e à esquerda.

As linhas arqueadas acompanham os rebordos costais direito e esquerdo.

O nome das nove regiões topográficas do abdômen, delimitadas segundo as linhas acima descritas, são: epigástrio, mesogástrio, hipogástrio, hipocôndrios (direito e esquerdo), flancos (direito e esquerdo) e fossas ilíacas (direita e esquerda), conforme indicado na Figura 1.

Considerando o esquema citado, quando um determinado fenômeno interessa as áreas 1,2 e 3 pode ser referido como localizado no andar superior do abdômen; igualmente, as áreas 4,5 e 6 compõem o andar médio e as áreas 7,8 e 9 o andar inferior do abdômen.

A segunda maneira de dividir topograficamente o abdômen, que pode facilitar a referência a dados da anamnese ou do exame físico, é a divisão em quadrantes, tomando-se, como referência, uma linha horizontal e outra vertical, que se cruzam exatamente na cicatriz umbilical. Dessa forma, o abdômen é dividido em quadrantes superiores, direito e esquerdo, e quadrantes inferiores, direito e esquerdo.

\section{2- Descrever a forma do abdômen, reconhe- cendo as de apresentação clínica mais fre- qüentes: plano, escavado, globoso, batráquio, avental}

O abdômen pode apresentar variações de forma, segundo idade, sexo e estado de nutrição, do estado dos músculos da parede abdominal, além da condição fisiológica da gravidez. As alterações da forma do abdômen podem, entretanto, adquirir significado diagnóstico. Dependem de alterações que ocorrem tanto no conteúdo da cavidade abdominal, como de alterações da parede abdominal, particularmente na musculatura e no subcutâneo. Podem ser de dois tipos: simétricas e assimétricas. As enunciadas neste item são do tipo de alterações simétricas.

$\mathrm{O}$ abdômen plano pode ser considerado como uma forma normal, muito embora o termo plano não

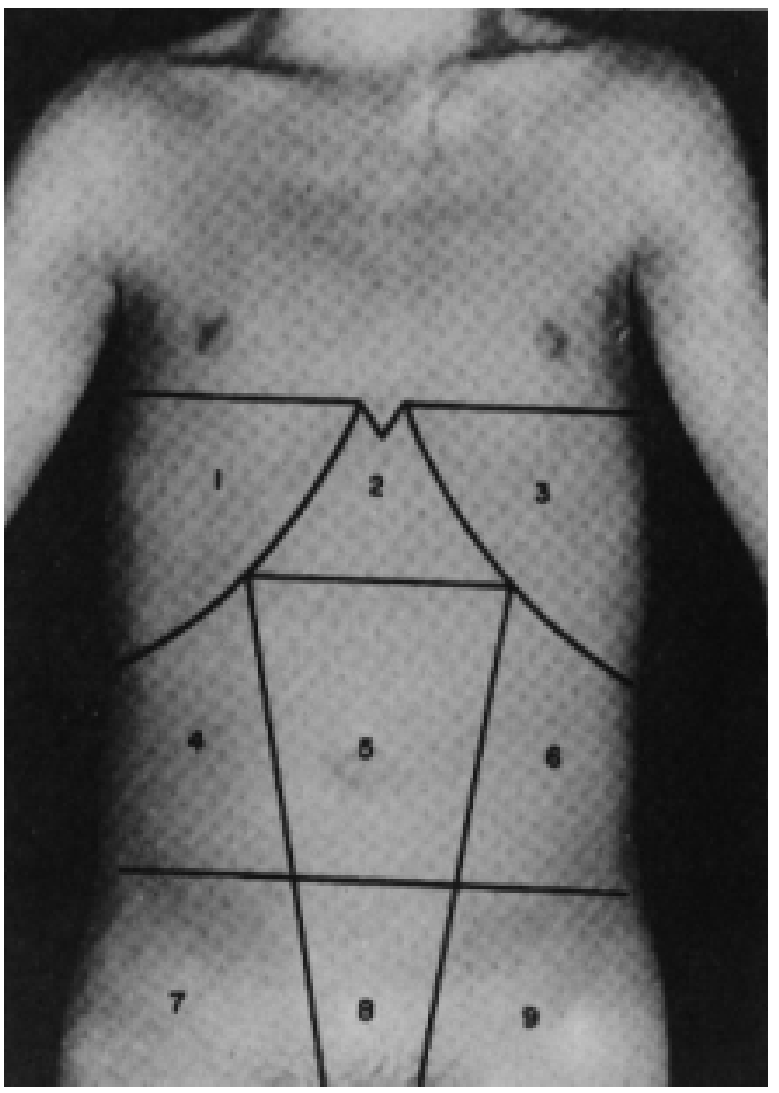

Figura 1 - Divisão topográfica do abdômen [Porto, $1992^{1}$ ] . Os pontos de referência estão mencionados no texto. As áreas definidas são as seguintes: 1 - hipocôndrio direito; 2 epigástrio; 3 - hipocôndrio esquerdo; 4 - flanco direito; 5 mesogástrio ou umbilical; 6 - flanco esquerdo; 7 - fossa ilíaca direita; 8 - hipogástrio ou suprapúbica; 9 - flanco esquerdo. 
seja apropriado para uma conformação curvilínea. $\mathrm{O}$ termo é relativo ao perfil do abdômen ao longa da linha mediana. Freqüentemente, o abdômen tem o perfil em forma de $\mathrm{S}$ deitado e aberto, com a parte mais bojuda localizada na região epigástrica. A forma pode ser considerada "plana" e não tem significado clínico.

Escavado, também chamado de retraído, é o abdômen que se caracteriza por encurtamento no sentido ântero-posterior, assumindo um aspecto côncavo, com os rebordos costais, as espinhas ilíacas e a sínfise púbica bem visíveis. É observado em pacientes muito emagrecidos, caquéticos e desidratados.

Globoso é o abdômen global e uniformemente crescido, com aumento predominante do diâmetro ântero-posterior. $\mathrm{O}$ abdômen de obesos, de pacientes com grandes ascites, com grande distensão gasosa das alças intestinais, com grandes crescimentos do fígado e do baço ou com cistos gigantes de ovário são do tipo globoso. Uma variante do globoso é o piriforme, caracterizado pelo aumento de volume, mas, o bom tônus da musculatura da parede deixa o abdômen "armado", praticamente sem aumento do diâmetro transversal. É observado nas grávidas.

Abdômen de batráquio é aquele cuja forma se caracteriza, estando o paciente em decúbito dorsal, pela dilatação exagerada dos flancos, que lhe dá aumento do diâmetro transversal e, visto de cima, uma conformação circular.

A forma em avental é observada, quando o grande acúmulo de tecido adiposo no subcutâneo faz com que o abdômen caia sobre as coxas, quando o paciente está em pé. É, portanto, observado nos grandes obesos. Uma variante do abdômen em avental é o pendular. Esse tipo tem, também, o aspecto de avental, mas, diferentemente deste, resulta de uma grande fraqueza da musculatura do andar inferior do abdômen, não necessariamente associada à obesidade. A causa mais comum do abdômen pendular é a flacidez abdominal do puerpério.

\section{3- Reconhecer abaulamentos e retrações locali- zadas e citar as principais causas dessas anor- malidades}

Tais anormalidades são modificações assimétricas da forma do abdômen e sempre têm significado patológico. Em geral, as assimetrias são dadas por abaulamentos localizados.

Os abaulamentos localizados podem ser devidos a: distensões ou crescimentos localizados de alças intestinais (meteorismo, megacólon chagásico), hérnias na parede abdominal, aumentos de tamanho de órgãos maciços (hepatomegalia, esplenomegalia), tumores (de qualquer dos órgãos abdominais ou pélvicos, linfomas e também retroperitoneais, como os renais), cistos (do ovário, hidáticos) e ao útero grávido.

É importante anotar a forma e a região em que está o abaulamento. Dados da palpação, percussão e ausculta serão fundamentais para o esclarecimento da anormalidade.

As retrações localizadas são eventualidades raras. A mais comum é observada no epigástrio de pacientes magros com evidente ptose visceral, particularmente, quando se põe de pé.

\section{4- Reconhecer a ocorrência de peristaltismo vi- sível, estabelecendo seu significado clínico}

Normalmente, não se observa, no abdômen, a presença dos movimentos peristálticos dos diversos segmentos do tubo gastrointestinal, subjacente. Entretanto, em pacientes com escasso ou nenhum tecido adiposo, além de músculos adelgaçados (emagrecidos ou caquéticos), pode-se identificar movimentos peristálticos das alças delgadas. Nesses casos, estarão sendo observados apenas movimentos peristálticos, normais.

A importância clínica da deteç̧ão do peristaltismo visível no abdômen reside no fato de que pode indicar obstrução localizada no antro gástrico, no intestino delgado ou nos cólons. Para melhor precisão diagnóstica, é necessário que se defina o local, o sentido e a freqüência ( $\mathrm{n}^{\circ}$ de movimentos / $\mathrm{min}$ ) com que ocorrem os movimentos peristálticos. É de suma importância, também, que sejam identificados fenômenos acústicos e outros sintomas acompanhantes, como será comentado abaixo.

O sinal, nem sempre, está presente. No caso de obstrução do intestino delgado, deve ser procurado, de preferência, durante as crises de dores que o acompanham. Quando suspeitado, mas não presente no momento do exame, pode-se estimular o aparecimento do peristaltismo, mediante sucessivas e breves compressões na parede abdominal.

- Peristaltismo visível, indicativo de obstrução no antro gástrico: a extensão da contração depende do grau de dilatação que adquiriu o estômago, podendo interessar epi, meso e até hipogástrio; o sentido do movimento costuma ser oblíquo, de cima para baixo e da esquerda para a direita, iniciando-se abaixo do rebordo costal, esquerdo, migrando lentamente, muitas vezes desenhando, em relevo, a forma do órgão na 
superfície do abdômen; a característica mais marcante do movimento peristáltico do estômago é sua freqüência: 3 ondas/ min, a mesma do ritmo elétrico de base da musculatura lisa do órgão, que limita a freqüência máxima de contrações. $\mathrm{O}$ sinal acústico e o sintoma acompanhante dependem da estase gástrica, causada pela obstrução. O sinal acústico é a patinhação e o sintoma é o vômito de estase, caracterizado pelo reconhecimento de alimentos ingeridos muitas horas antes, mais de seis, no material vomitado.

As causas mais comuns de obstrução da região do antro gástrico são o câncer gástrico e as úlceras pépticas, estenosantes.

- Peristaltismo visível, indicativo de obstrução no intestino delgado: o movimento localiza-se na região umbilical ou em sua imediações, não tem direção constante e pode-se observar mais de uma onda, ocorrendo simultaneamente, em pontos diferentes, tornando praticamente impossível estabelecer sua freqüência. Os fenômenos acompanhantes decorrem da luta do intestino para vencer o obstáculo. As dores fortes costumam aparecer e desaparecer com as ondas peristálticas e serem acompanhadas por aumento da intensidade dos ruídos hidroaéreos, que podem assumir timbre metálico ou serem audíveis à distância, sem o auxílio do estetoscópio. Se a obstrução estiver no intestino delgado, proximal, podem ocorrer vômitos escuros de odor fecalóide.

As causas mais comuns de obstrução do intestino delgado são: na criança, anomalias congênitas, intussuscepção, divertículo de Meckel, "bolo" de áscaris e corpos estranhos; no adulto, aderências por operações prévias, hérnias encarceradas, doença de Crohn, tumores benignos e malignos, compressões extrínsecas.

- Peristaltismo visível, indicativo de obstrução nos cólons: a localização pode ser em qualquer das regiões em que se projetam os cólons na parede abdominal, e a direção do movimento é a mesma do trânsito normal. É mais evidente o peristaltismo visível do cólon transverso. A presença de dilatação, como no caso do megacólon chagásico, facilita a percepção do movimento intestinal. O movimento visível dos cólons costuma ser lento, como o do estômago, porque, nem sempre, é verdadeiramente peristáltico. $\mathrm{O}$ fenômeno acústico presente pode ser aumento dos ruídos hidroaéreos e o sintoma acompanhante costuma ser parada da emissão de fezes e gazes.

As causas mais comuns de obstrução dos cólons são o câncer de cólon e o megacólon chagásico, especialmente, se foi formado fecaloma.

\section{5- Descrever as características de localização da rede venosa, visível e do sentido da corrente sangüínea na circulação colateral, decorrente da obstrução dos seguintes sistemas venosos: porta, cava inferior, cava superior e mistos}

O reconhecimento de circulação colateral, no abdômen, é dado de muita importância para o estabelecimento do diagnóstico de obstrução que pode ocorrer nos principais sistemas venosos do organismo. As veias que conduzem um caudal aumentado de sangue caracterizam-se pela dilatação e tortuosidade. A não visualização dessas veias, na parede abdominal, não exclui a possibilidade de presença de circulação colateral, pois pode ser explicada pela presença de espesso tecido adiposo ou edema local.

A clara determinação do sentido da corrente sangüínea é de fundamental importância para que se saiba qual dos sistemas referidos está obstruído. Outros achados do exame físico e das informações obtidas pela anamnese deverão entrar, também, no processo de raciocínio diagnóstico.

Deve ser entendida como colateral a circulação venosa, que apresenta um caudal anormalmente aumentado, podendo haver ou não a inversão do sentido normal da corrente sangüínea. É imprescindível que se conheça em que regiões se situam as conexões entre os sistemas venosos e o sentido normal da corrente sangüínea das veias subcutâneas do abdômen.

A conexão do sistema portal com a circulação venosa, superficial, do abdômen faz-se pelas veias paraumbilicais, que desembocam na veia portal, esquerda; essas veias são operantes durante a vida intrauterina, porém fecham-se a partir do nascimento, mas podem ser permeadas, se ocorrer hipertensão portal. As conexões entre o sistema cava inferior e o superior, existentes na periferia do abdômen, situam-se, aproximadamente, na linha transversal que passa pela cicatriz umbilical.

- Circulação colateral do tipo portal - é o tipo de circulação colateral, que mais freqüentemente se observa na prática médica. Ocorre, quando se estabelece obstáculo ao fluxo venoso, proveniente do tubo digestivo e do baço, em direção ao fígado.

Considerando como referência os sinusóides hepáticos, na dependência do local em que está o obstáculo ao fluxo portal, a hipertensão portal pode ser: pré-sinusoidal, sinusoidal ou pós-sinusoidal. A pré-sinusoidal pode ocorrer em situação pré-hepática (exemplo, trombose de veia porta) ou intra-hepática, no espaço porta (exemplo, esquistossomose mansônica); a 
sinusoidal depende de obstáculo dos próprios sinusóides, portanto, na intimidade do parênquima hepático (exemplo, cirrose hepática); a pós-sinusoidal pode ser devida a obstáculo nas veias centrolobulares (exemplo, doença venoclusiva) ou nas veias supra-hepáticas (exemplo, síndrome de Budd-Chiari). À exceção da hipertensão pré-sinusoidal, pré-hepática, quando o regime de hipertensão não afeta o ramo esquerdo da veia porta, nas demais, a hipertensão reinante força a vazão pelas veias paraumbilicais, que levam o sangue portal para a região umbilical, periférica. Nas hipertensões portais, pós-sinusoidais, a elevação da pressão no ramo esquerdo da veia porta não é muito expressivo, razão pela qual a circulação colateral pode ser pequena.

Na periferia, o sangue portal chega à região umbilical e adjacências, onde existe a conexão entre os dois sistemas cava, acima descritos. Em conseqüência, o sangue venoso, proveniente do ramo esquerdo da veia porta, toma um ou outro caminho, na dependência do local em que aflorou.

Assim, a circulação colateral, visível acima da cicatriz umbilical, drena em direção ascendente para o sistema cava superior, enquanto que a que está abaixo do mesmo ponto drena para baixo, em direção à cava inferior. Em outras palavras, a circulação colateral, visível, do tipo porta caracteriza-se por manter o sentido normal da circulação venosa, periférica, do abdômen, sempre em direção centrífuga em relação ao umbigo (Figura 2); apenas o caudal está aumentado. Em geral, as veias dilatadas costumam ser melhor per-

\section{Circulação colateral superficial}
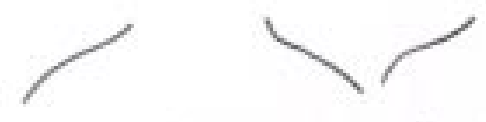

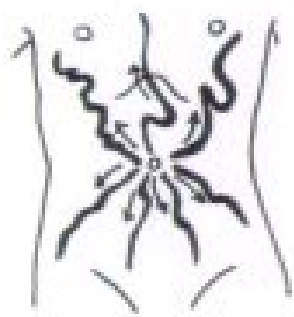

tipo porta

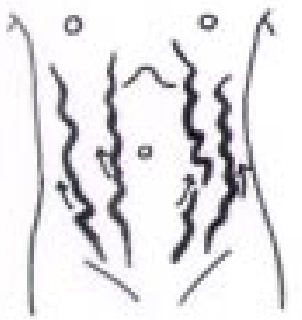

tipo caa iferior

Figura 2 - Esquema ilustrativo da disposição aproximada e do sentido da corrente sangüínea das circulações colaterais, superficiais, do tipo portal e do tipo cava inferior, no abdômen. cebidas em território acima da cicatriz umbilical. Quando as veias tortuosas e engrossadas, tornam-se exuberantes em torno do umbigo, caracteriza-se o que é conhecido como cabeça de medusa (caput medusae), muito raramente observada.

- Circulação colateral, tipo cava inferior - as ectasias venosas são observadas mais nitidamente no andar inferior do abdômen e nas suas regiões laterais. $\mathrm{O}$ sentido da corrente será sempre ascendente, uma vez que a circulação está toda direcionada para a cava superior (Figura 2). A principal causa de obstrução da veia cava inferior é a trombose.

- Circulação colateral, tipo cava superior - eventuais vasos ectasiados, vistos na parte superior do abdômen, têm sentido de corrente para baixo, na procura de conexão com a cava inferior.

- Circulação colateral, tipo misto - costuma ser uma associação entre os dois primeiros descritos e caracteriza-se por ampla rede venosa, colateral, com sentido de circulação para cima. Outros achados do exame físico, dados de anamnese e também subsidiários completarão o diagnóstico.

\section{6- Posicionar adequadamente o paciente para a palpação do abdômen, evitando as posturas inconvenientes ou prejudiciais ao exame}

Principalmente para a palpação do abdômen, mas, também, para os demais métodos semiológicos, o paciente deve ser posicionado em decúbito dorsal, em mesa de exame provida de colchonete ou na cama comum de enfermaria, com os membros superiores e inferiores estendidos. Um pequeno travesseiro deve suportar a cabeça e os ombros, e um outro pode ser colocado sob os membros inferiores, para manter os joelhos levemente fletidos. O objetivo é colocar o paciente em posição favorável a que se obtenha o máximo de relaxamento muscular da parede anterior do abdômen; a posição não deve restringir a liberdade de atuação do examinador. Posturas inconvenientes são: pernas cruzadas, pescoço excessivamente fletido, braços elevados com as mãos sob a nuca, tronco fletido, ausência de suporte para a cabeça e ombros.

Toda a extensão do abdômen deve ser exposta, desde os hipocôndrios até as fossas ilíacas, a fim de não se perder qualquer sinal que possa ser importante para o diagnóstico.

Evidentemente, o local de exame deverá ser silencioso, calmo, bem iluminado, de preferência com luz natural, e ter temperatura adequada, evitando-se o frio que tensiona a parede abdominal. 


\section{7- Efetuar a palpação superficial do abdômen, ve- rificando as condições da parede abdominal no que se refere à espessura, continuidade, toni- cidade e deformações por alterações mais pro- fundas (visceromegalias, tumorações, etc.)}

A melhor posição que o médico deveria assumir para efetuar a palpação do abdômen, tanto a superficial como a profunda, seria sentar-se na cama ou mesa de exame, à direita (para os destros), na altura da parte inferior da coxa do paciente. Essa atitude daria confiança ao paciente, permitiria melhor visualização de sua mímica durante o exame e colocaria as mãos do examinador em posição bem adequada. Atualmente, tem sido recomendado que o médico não se sente na cama do paciente, tendo em vista a luta contra a infecção hospitalar. Assim, hoje, a palpação deve ser realizada pelo examinador em pé, ao lado do doente deitado. As mãos não devem estar frias a ponto de provocar reações desagradáveis ao paciente, ao exame; se estiverem frias, recomenda-se friccionálas uma contra a outra, para aquecê-las. O paciente deve ser prevenido de que não se lhe causará desconforto maior e que deve se manifestar caso sinta dor ou qualquer sensação desagradável.

A palpação superficial, inicial deve ser feita com as duas mãos relaxadas, tocando-se suavemente, o abdômen do paciente. O examinador deve palpar, com delicadeza, toda a extensão do abdômen, comparando, simultaneamente, áreas direitas e esquerdas, respectivamente com suas mãos esquerda e direita. A palpação comparativa pode detectar pequenas, mas importantes diferenças, notadamente na tonicidade da musculatura e na sensibilidade, entre áreas direita e esquerda do abdômen, não perceptíveis de outra maneira. Toda a face palmar das mãos deve tocar o abdômen do paciente. A tonicidade da musculatura e a sensibilidade à pressão (leve) serão avaliadas durante movimento de flexão dos quatro dedos externos (exclui-se o polegar) que comprimem levemente a parede. A força de flexão dos dedos deve ser bem graduada, executando-se dois ou três movimentos em crescendo, em cada área, sem excessos, pois, não se sabe, de início, qual a sensibilidade que se vai encontrar. O tatear palpatório também orienta o médico sobre a presença de anormalidades estruturais da parede (exemplo, orifícios herniários) ou de alterações na cavidade abdominal ou pélvica (exemplos, hepato e esplenomegalias, tumores, ascite, cistos, útero grávido). O detalhamento palpatório, superficial, de uma anor- malidade será feito com uma das mãos.

A palpação superficial serve para fixar a atenção do médico no que possa existir de anormal no abdômen, orientando o prosseguimento do exame, para ganhar a confiança do paciente e para executar a palpação profunda.

\section{8- Discutir os mecanismos responsáveis por hi- pertonia, localizada ou generalizada, da pare- de abdominal}

A hipertonia da parede abdominal, revelada pela resistência oposta à palpação, decorre de contração forte da musculatura e pode ser de origem voluntária ou involuntária.

A hipertonia voluntária, ou falta de relaxamento da musculatura abdominal, é decorrente de posicionamento inadequado do paciente, do frio que ele pode estar sentindo, por sentir cócegas, por tensão emocional ou pelas frias mãos do examinador. Já foram mencionados os meios para que tais inconveniências sejam evitadas.

A contração espasmódica, involuntária resulta da irritação do peritônio parietal, subjacente, causada por agente infeccioso (exemplo, apendicite aguda), químico (exemplo, ácido clorídrico, gástrico, na perfuração de úlcera péptica, em peritônio livre) ou neoplásico (exemplo, metástases peritoneais). Geralmente, esse tipo de hipertonia é localizado, enquanto a voluntária é generalizada. A dor é provocada, quando o paciente tenta levantar o tronco, sem utilizar-se dos braços, porém, a hipertonia não é necessariamente dolorosa. A hipertonia ocorre em correspondência com a área irritada, de peritônio parietal (exemplo, no processo inflamatório agudo, que atinge o apêndice e o peritônio parietal, adjacente, a hipertonia se revela na fossa ilíaca, direita). No início do processo irritativo do peritônio, o grau de hipertonia é pequeno, só detectável por acurado exame, mas evolui, acompanhando a intensidade e a extensão da irritação, culminando no grau extremo de rigidez generalizada, conhecida como "abdômen em tábua".

A palpação superficial, bimanual, acima mencionada é importante método semiológico para detectar as hipertonias localizadas. A hipertonia involuntária, generalizada é indicativa, igualmente, de irritação peritoneal, generalizada.

Com os dados obtidos na anamnese e outros achados do exame físico, além de diferenciar a hipertonia voluntária da involuntária, o médico pode elaborar a hipótese diagnóstica, mais provável. 


\section{9- Efetuar a palpação profunda e deslizante do abdômen, identificando os segmentos do tubo digestivo, examináveis por essa técnica}

A palpação profunda e deslizante visa palpar alguns órgãos contidos na cavidade abdominal e eventuais "massas" ali existentes. Nenhum dos segmentos do intestino delgado é individualizado por meio desse método. Eventualmente, consegue-se palpar a grande curvatura do estômago e os cólons ascendente e descendente. O ceco, o transverso e o sigmóide são facilmente palpáveis. O médico deve anotar as alterações que percebeu nas estruturas palpadas, incluindo variações na sensibilidade, consistência, diâmetro, forma e mobilidade.

A posição do paciente e a do médico, para executar a palpação profunda e deslizante, são as mesmas anteriormente descritas. Como já foi mencionado, o médico deve fazer a palpação, colocando-se em pé à direita ou à esquerda do paciente, de acordo com o órgão a ser examinado, embora, tecnicamente, a melhor posição é a sentada à beira do leito ou da mesa ocupada pelo paciente, bem junto a este. Costuma-se iniciar o exame à direita do paciente e terminar com a palpação do descendente e sigmóide, à esquerda.

Conforme o órgão a explorar, a palpação pode ser uni ou bimanual. Quanto à posição das mãos há uma regra geral: as mãos que palpam devem ser colocadas de modo tal que seu maior eixo seja perpendicular ao eixo longitudinal da porção do intestino que se queira explorar. A mão, levemente fletida, deve fazer um ângulo, mais ou menos agudo, com a parede anterior do abdômen, o grau de obliqüidade orientado pelo médico em cada caso, isoladamente. Por vezes, devido ao excessivo volume do abdômen, é necessário que se aplique a mão quase que perpendicularmente. Como regra geral, o ângulo formado fica por volta de 45 graus.

Quando a palpação é bimanual, as mãos devem ser dispostas de tal forma que se forme, entre elas, um ângulo agudo com a abertura voltada para o examinador. A palpação será feita pelas extremidades dos dedos, predominantemente com a face palmar da terceira falange. Pode-se usar quatro, três ou dois dedos de cada mão, desde que a linha que suas extremidades formem seja retilínea, quando se justapõem numa superfície plana. A palpação feita com a mão nessa posição já foi denominada de "oblíqua, com a fila dos últimos dedos", na qual, a fila dos últimos de- dos dispõe-se ao longo do comprimento, ao passo que as mãos se colocam oblíquamente à direção da víscera a ser examinada. Em geral, usam-se o terceiro e o quarto dedo de cada mão para compor a linha reta que vai deslizar sobre o órgão a examinar.

O método de palpação profunda e deslizante é realizado em dois tempos.

\section{1) Posicionamento das mãos no abdômen até um plano profundo resistente}

Um princípio básico deve nortear todo o processo do método: palpação profunda não quer dizer que seja realizada com força. A posição da mão e dos dedos, acima descrita, não deve ser fixa, rígida. Todo o processo de palpação exige a conservação dos movimentos dos dedos, porque o movimento é parte integrante na percepção palpatória. A aquisição dessa habilidade costuma ser a que mais treinamento exige do aprendiz.

A facilidade para o posicionamento das mãos, no plano profundo, dependerá do tono da musculatura da parede abdominal anterior, da espessura do panículo adiposo, da presença de dor, da pressão intra-abdominal e do conteúdo das alças intestinais. A dificuldade maior costuma ser dada pela hipertonicidade dos músculos abdominais. O médico deve estar prevenido para usar mais técnica e menos força, para vencer as dificuldades e alcançar o objetivo da palpação profunda e deslizante. Já foram mencionadas algumas condutas para reduzir a tonicidade dos músculos abdominais, mas, um importante ponto a ser observado é abordado a seguir.

A manobra de aprofundar as mãos até alcançar um ponto profundo, a partir do qual será feito o deslizamento, exige estrita observação dos movimentos respiratórios do paciente. Durante a inspiração, ocorre aumento da tensão da musculatura abdominal e elevação da pressão intra-abdominal, ambos desfavoráveis à manobra pretendida. Ao contrário, na expiração, há diminuição de ambos, tornando essa fase da respiração a mais propícia para a penetração das mãos e, também, para o deslizamento que será feito em seguida.

Existem pessoas que têm a tendência de tornar a expiração forçada, quando se chama sua atenção para seu ato respiratório, dificultando ou tornando impossível a palpação. Por tal razão, é preferível, inicialmente, procurar fazer a palpação sem pedir ao paciente que faça, desta ou daquela maneira, seu ato de respirar. Se julgar necessária respiração mais favorá- 
vel, o médico pode demonstrar ao paciente como ele deve proceder, realizando dois, três ou mais movimentos respiratórios, calmos, sempre com a mesma freqüência e de amplitude moderada. A respiração poderá ser feita pela boca ou pelas fossas nasais, conforme for mais adequado para o paciente e para o médico; o importante é obter boas condições de relaxamento expiratório dos músculos para o aprofundamento das mãos e para o deslizamento. Quando a palpação é dificultada pela dor, o médico deve tentar, com delicadeza, as manobras necessárias, mas abandonar o procedimento, se for grande o sofrimento do paciente.

Ao fazer-se o aprofundamento das mãos, durante uma ou mais expirações (durante as inspirações as manobras cessam, mantendo-se a posição até então alcançada), o médico vai impelindo a pele em direção oposta ao sentido em que se vai fazer o deslizamento, de modo a formar várias dobras cutâneas acima da ponta dos dedos. As sobras de pele serão utilizada para a realização do deslizamento.

\section{2) Deslizamento}

O deslizamento é sempre feito contra um plano profundo, resistente. Para a palpação do transverso e da grande curvatura do estômago, o deslizamento é feito na linha mediana, sobre a coluna vertebral. Nos flancos (palpação dos cólons ascendente e descendente), uma das mãos faz as vezes do plano profundo, resistente, enquanto a outra desliza sobre a víscera. Nas fossas ilíacas (palpação do ceco e do sigmóide), as manobras são feitas sobre os ossos ilíacos.

Conseguindo-se atingir o adequado plano profundo e havendo sobras de pele recolhidas acima dos dedos, durante uma expiração, será realizado um amplo movimento de deslizamento da(s) mão(s) sobre o plano profundo. Durante o deslizamento, os dedos deslocam-se não sobre a pele, mas, com as sobras de pele recolhidas, aproveitando-se da mobilidade da derma sobre os planos musculoaponevróticos. A pele, portanto, participa como um revestimento para os dedos, durante o deslizamento. Durante o movimento de deslizamento, é que deverão ser avaliadas as características do órgão que está sendo examinado.

A influência dos movimentos respiratórios sobre a palpação profunda e deslizante é grande no que tange ao transverso e à grande curvatura do estômago, mas é mínima nos flancos e no andar inferior do abdômen. Como para com o aprofundamento da mão, no deslizamento, deverá ser usado o mínimo de força e o máximo de técnica, para se ter o máximo de sensibilidade.
Quando a parede abdominal for flácida ou o paciente muito magro, a palpação das vísceras abdominais é grandemente facilitada.

\section{0- Efetuar a palpação profunda do abdômen, identificando tumorações abdominais, even- tualmente presentes, e caracterizando-as quanto às seguintes variáveis: localização, forma, consistência, mobilidade, sensibilida- de, dimensões, pulsatilidade}

Ao serem realizadas as manobras de palpação, poderão ser encontradas massas abdominais, que podem corresponder a tumores malignos ou benignos, cistos das mais variadas naturezas, conglomerados de gânglios ou a um órgão normal, apenas fora de seu sítio anatômico, normal, como é o caso do rim ptótico, quase sempre, o direito.

Localização, sensibilidade, consistência, dimensão, forma, superfície, mobilidade e pulsatilidade devem ser anotadas. Essas características poderão delimitar as hipóteses diagnósticas, consideradas em cada caso.

- Localização: limita o número de órgãos a considerar (exemplo, massa no quadrante superior esquerdo, considerar afecções do baço, do ângulo esplênico do cólon e adjacências e do rim esquerdo), deve-se ter em mente a projeção dos diversos órgãos das cavidades abdominal e pélvica e do retro-peritônio nas áreas da divisão topográfica do abdômen.

- Sensibilidade dolorosa: a dor provocada pela palpação de uma massa abdominal é devida a processo inflamatório (exemplo, plastrão de epíplon numa apendicite aguda, massa inflamatória na doença de Crohn) ou à distensão da cápsula do órgão (exemplos, fígado ou baço agudamente distendidos)

- Dimensão: é a característica que informa sobre o tamanho da estrutura patológica em cena, mas não indica, necessariamente, a gravidade. Tanto processos malignos como benignos podem assumir grandes proporções de tamanho. Dependendo das dimensões, podem ser visíveis à inspeção do abdômen, percebida pelo próprio paciente e, muitas vezes, o motivo da consulta clínica.

- Forma: cistos, pseudocistos pancreáticos, tumores sólidos, geralmente, são de conformação esférica. A forma pode identificar o órgão aumentado, levando-se em conta, também, a localização (exemplos, fígado, baço, rim). 
- Consistência: é apreciada pela resistência da massa à palpação, podendo variar conforme o processo patológico (exemplos, o carcinoma de fígado pode ser pétreo, o baço aumentado por causa de uma infecção pode oferecer pouca resistência à compressão (consistência mole, branda ou flácida).

- Superfície: pode ser lisa (exemplos: cistos ou pseudocisto, hepatite, esteatose hepática) ou nodular (exemplos: tumores, cirrose hepática).

- Mobilidade: uma massa que se move, acompanhando os movimentos respiratórios, indica que está relacionada a uma das vísceras móveis ou ao mesentério, portanto, dentro da cavidade peritoneal. A massa que não se move deve estar localizada no retroperitônio ou corresponder a neoplasia infiltrativa de estruturas fixas.

- Pulsação: uma massa que pulsa no abdômen pode ser uma dilatação de artéria, ou seja, um aneurisma da aorta abdominal. Deve ser entendido por pulsação a percepção de aumento intermitente do volume da massa a cada sístole cardíaca. Entretanto, uma massa sólida, encostada na aorta pode transmitir a pulsação da artéria; nesse caso, a massa é empurrada a cada sístole, mas ela não apresenta variação de seu tamanho de acordo com o pulso sistólico, central.

\section{1- Discutir o significado clínico de dor à des- compressão brusca do abdômen, mencio- nando as causas mais freqüentes da anor- malidade}

A dor, à descompressão brusca do abdômen, é sinal indicativo de inflamação aguda do peritônio, ou seja, peritonite aguda. É causada pela colonização de bactérias nos folhetos peritoneais, a partir de um foco situado no próprio abdômen (exemplo, apendicite, colecistites, diverticulites agudas) ou fora dele, por via hematogênica (exemplo, septicemias), por aberturas na parede abdominal (exemplo, perfurações da parede abdominal) ou por translocação de bactérias existentes nos intestinos (peritonite espontânea em ascite). A peritonite também pode ser de natureza química (exemplo, material acidopéptico em úlcera duodenal, perfurada). A zona inflamada do peritônio é a que responde com dor à descompressão brusca.

Antes de pesquisar a dor à descompressão brusca deve ser feita a palpação superficial, delicada, em toda a extensão do abdômen; localizado um ponto ou área dolorosa, ou mesmo se ela é referida espontaneamente pelo paciente, vai-se comprimindo lenta e gra- dualmente; a dor acentua-se à medida que a mão vai aprofundando; em seguida, retira-se bruscamente a mão. O sinal é positivo, quando o paciente apresenta dor aguda com esse último movimento, geralmente, expressando verbal e mimicamente a sensação desagradável. Evidentemente, o paciente deve ser prevenido da manobra e do que vai sentir, uma vez que a dor pode ser muito intensa. É o sinal de Blumberg.

Acompanhando o sinal da dor à descompressão brusca, observa-se hipertonia da musculatura no local, como outro indicativo da peritonite. A contração pode ser forte e contínua, mas, pode ocorrer somente quando se exerce pressão, mesmo que suave, com os dedos; é como se fosse chamada a atenção dos músculos para que eles se contraiam no sentido de defender a parte subjacente e inflamada. A resistência muscular, mesmo em peritonite grave, pode ser pequena, se os músculos abdominais forem fracos. Dependendo da causa determinante do peritonismo, outros sinais e sintomas auxiliarão no diagnóstico.

A dor à descompressão brusca e a resistência da parede compõem o que pode ser chamado de sinais de peritonismo. A dor no exato ponto da inflamação do peritônio decorre do comprometimento do peritônio parietal ou do mesentério, uma vez que essas estruturas são supridas por nervos cérebro-espinais que têm fina representação no cérebro, ao contrário da inervação visceral.

Pode-se distinguir casos de peritonite localizada e de peritonite difusa. A peritonite localizada ocorre quando o processo infeccioso atinge o peritônio das vizinhanças de um órgão (exemplo, apendicite, colecistite, diverticulite). $\mathrm{O}$ grande epíplon tende a se fixar na região inflamada, circunscrevendo e tendendo a isolar o foco inflamado. A difusa ocorre pela expansão de uma localizada, ou por rápido comprometimento da generalidade do peritônio (exemplo, peritonite espontânea, septicemia).

\section{2- Efetuar a detecção dos ruídos hidroaéreos em suas variedades: patinhação, gargarejo e borborigmo}

Os fenômenos acústicos, que ocorrem no abdômen podem ser audíveis por intermédio do estetoscópio ou à distância. Podem ser percebidos sem se tocar o abdômen, durante a palpação ou em manobras manuais de provocação. Neste item, serão abordados apenas os que são audíveis sem o estetoscópico.

A presença de gases é indispensável para a produção de ruídos, uma vez que eles são produzidos por 
turbilhões sonoros do componente líquido, daí a denominação de ruídos hidroaéreos; de maneira geral, eles são tanto mais evidentes quanto maior for a quantidade de líquidos em relação à de sólidos. Aparecem no indivíduo normal, mas, há ruídos que indicam processo patológico. Ocorrem, normalmente, com pouca freqüência no intestino delgado, mostrando-se mais freqüentes no intestino grosso e no estômago. Há quatro tipos de ruídos hidroaéreos de interesse semiológico.

1) Patinhação - assemelha-se ao que se obtém, quando são dadas palmadas em uma superfície com água. É obtido em órgãos de grande diâmetro, como o estômago e o ceco, com paredes flácidas e com conteúdo líquido, que faz nível no seu interior. Pesquisa-se, comprimindo rapidamente a parede do abdômen com a face palmar de três dedos medianos da mão. A parede do órgão é forçada a bater de encontro com a superfície líquida, produzindo um ruído do tipo clap, clap. É observado no caso de aumento do conteúdo líquido do estômago, quando o órgão se esvazia mal, como na obstrução de antro ou piloro.

2) Gargarejo - é o mais característico dos ruídos abdominais, percebidos quando é feita a palpação profunda e deslizante, particularmente no ceco. Além de ouvir-se o ruído, tem-se a percepção tátil da presença do conteúdo hidroaéreo da víscera.

3) Borborigmo - é dado pela grande predominância de gases em relação ao conteúdo líquido do órgão. É o "ronco da barriga", que indivíduos normais freqüentemente apresentam, quando estão com fome; ouve-se à distância, quando o estômago vazio apresenta uma forte onda de contração em direção ao piloro. Tal tipo de ruído pode ser considerado como uma variante do ruído hidroaéreo propriamente dito, descrito anteriormente. Em casos de obstrução incompleta do intestino, o ruído hiperativo pode ser audível até a um ou dois metros do paciente.

\section{3- Discutir o significado clínico da ocorrência ou não de ruídos hidroaéreos}

A resposta a essa questão está no item 27.

\section{4- Descrever as características normais, de per- cussão do abdômen nas suas diferentes re- giões}

A percussão costuma ser a último das quatro etapas de exame clínico do abdômen, após a inspeção, ausculta e palpação. A posição do paciente é a mesma das etapas anteriores do exame. $\mathrm{O}$ médico faz a percussão em pé, à direita ou à esquerda do paciente.

Quatro tipos de sons podem ser obtidos pela percussão do abdômen: timpânico, hipertimpânico, submaciço e maciço.

O timpanismo, dado pela presença de conteúdo gasoso no interior do tubo digestivo, é o som que é apresentado pelo abdômen normal em, praticamente, toda sua extensão. Na posição supina, o som é mais nítido em área de projeção do estômago, na superfície da parede abdominal. A razão é o conteúdo gasoso, costumeiramente, conhecido como "bolha gástrica", reconhecido facilmente em radiografia simples do abdômen, com o paciente em pé. A área do nítido timpanismo é conhecida como espaço de Traube, de imprecisa delimitação. O som timpânico, de uma determinada área do abdômen pode ser substituído por submacicez ou macicez, se ela for ocupada por estrutura sólida ou líquida. Assim, o timpanismo que caracteriza o espaço de Traube pode ser substituído por macicez ou submacicez, se uma grande esplenomegalia, um tumor peritoneal ou retroperitoneal, um pseudocisto ou um tumor pancreático, ou uma grande hepatomegalia deslocar, suficientemente, o estômago. $\mathrm{O}$ achado de "espaço de Traube, livre" ou, muito raramente, "espaço de Traube, ocupado", como comumente encontra-se em observações clínicas, em nosso meio, é de paupérrimo significado clínico. A propósito, o pequeno significado clínico do espaço de Traube contrasta, enormemente, com a grande contribuição que o mesmo Ludwig Traube deu ao desenvolvimento da medicina experimental e à propedêutica clínica na Alemanha do século XIX. O espaço de Traube também não deve ser confundido com a área normal de percussão do baço.

O hipertimpanismo, um timpanismo de timbre mais sonoro, é observado, quando o conteúdo aéreo do tubo gastroentérico apresenta-se aumentado, como no meteorismo, na obstrução intestinal, no pneumoperitônio, no volvo e no megacólon chagásico.

Uma menor quantidade de gases ou a presença de um órgão maciço nas proximidades pode produzir um som submaciço.

A percussão sobre uma área sólida revela o som maciço. É o típico som que se obtém, quando da percussão do fígado no hipocôndrio direito. O desaparecimento da macicez hepática pode ser devido à interposição de alça intestinal, meteorismo, tórax enfisematoso e ao pneumoperitônio. No abdômen agu- 
do, o desaparecimento da macicez hepática é conhecido como sinal de Jobert e indica perfuração de víscera oca em peritônio livre, em geral, uma úlcera péptica. A percussão não é método recomendado para a identificação do local onde está localizado o bordo hepático, nas hepatomegalias, por ser imprecisa para tal finalidade.

A percussão é excelente recurso semiológico para o diagnóstico da ascite.

\section{5- Descrever as alterações da percussão ab- dominal para o diagnóstico da ascite}

Ascite é o nome dado ao derrame de líquido livre na cavidade abdominal. Esse acúmulo pode ter muitas causas, as quais podem fazer variar o volume (pode ser superior a 20 1), a aparência, a natureza e a composição do líquido. O exame acerca das propriedades físicas, do teor de certos componentes, da celularidade, da presença de células neoplásicas e de bactérias contaminantes do peritônio é de grande valor diagnóstico. O abdômen pode mostrar-se mais ou menos flácido ou, então, tenso, caracterizando a chamada ascite hipertensa. A presença de hérnia umbilical é achado freqüente nas grandes ascites. A causa mais freqüente de ascite é a cirrose hepática.

Os principais sinais que diagnosticam a presença de ascite por meio da percussão do abdômen são os indicados a seguir.

1) Sensação de onda ou sinal do piparote - a face palmar de uma das mãos é posicionada em um dos flancos; a seguir, a ponta do dedo médio, dobrado, apoiado e em estado de tensão contra a face palmar do polegar é disparada contra o outro flanco. $\mathrm{O}$ abalo produzido pelo piparote produz pequenas ondas de choque no líquido ascítico, perceptíveis pela palma da mão, colocada no flanco oposto. O choque pode ser percebido em casos de panículo adiposo e exagerado ou de edema na parede abdominal. Nesse caso, um assistente, ou o próprio paciente, coloca a borda cubital de sua mão sobre a linha mediana, no abdômen central, exercendo um pouco de pressão, a fim de interceptar ondas transmitidas pela parede, mas não impedindo a passagem da onda de choque do líquido ascítico. Esse sinal é próprio das grandes ascites, não sendo efetivo para ascites de médio ou pequeno porte. $\mathrm{O}$ sinal pode ser positivo, quando da presença de grandes tumores líquidos no abdômen (exemplo, cisto de ovário).
2) Semicírculos de Skoda - com o paciente em decúbito dorsal ou em pé, o líquido ascítico coletase nas partes mais declives, ou seja, flancos e andar inferior do abdômen. Sendo assim, a percussão, feita desde o andar superior, delimitará uma linha semicircular na transição entre o timpanismo e a macicez ou submacicez das áreas correspondentes às porções mais declives; a concavidade da linha semicircular estará voltada para a região epigástrica. Esse sinal poderá fazer o diagnóstico diferencial entre ascite e cisto gigante de ovário, uma vez que, na doença ginecológica, a concavidade da linha semicircular estará voltada para o púbis. Tal recurso semiológico foi uma contribuição de Josef Skoda, eminente diagnosticista da Universidade de Viena, no século XIX.

3) Macicez móvel - Como o líquido livre, na cavidade peritoneal, se acumula nas porções mais declives, quando o paciente se coloca em um dos decúbitos laterais, para aquele lado a massa líquida se dirigirá. Uma primeira percussão será feita no flanco esquerdo, com o paciente inclinado para sua esquerda, quase em decúbito lateral, esquerdo; o líquido ascítico ali acumulado propiciará som maciço ou submaciço; o paciente, então, vira-se e coloca-se em decúbito lateral direito, mantido o dedo de percussão no mesmo local em que se verificou a macicez. A segunda percussão, efetuada no mesmo ponto em que foi feita a primeira, vai produzir som timpânico. A contra-prova pode ser feita, mudando-se o local de percussão para o flanco direito, sempre tendo em mente o princípio de que o líquido e a correspondente macicez sempre se movem para as partes mais declives da cavidade abdominal.

Dentro do mesmo princípio, a percussão do abdômen pode ser feita com o paciente em outras posições, para se evidenciar a macicez móvel. Com o paciente em posição de Trendelenburg (paciente estendido com os pés em posição mais elevada do que a cabeça) um grande derrame líquido na cavidade peritoneal tornará maciça a região epigástrica. Uma pequena ascite, porém, poderá ser detectada com o paciente ajoelhado sobre a mesa de exame e com o tronco sustentado pelas mãos, com os braços estendidos em posição popularmente conhecida como "de quatro". A macicez será observada à percussão da região umbilical, pois, a parte da cavidade peritoneal correspondente será a mais declive na posição adotada. 
16- Descrever os achados da percussão do abdômen, que permitem diferenciar a ascite de grandes cistos ou tumores (exemplo: de ovário ou de pâncreas)

O líquido ascítico, livre na cavidade peritoneal, procura as partes mais declives. Ao contrário, os líquidos dos cistos, pseudocistos ou tumores líquidos são contidos pelas próprias estruturas do processo patológico. Assim, as linhas curvas que delimitam os limites entre timpanismo e macicez ou submacicez têm conformações distintas, conforme descrito no item 15.

\section{7- Esquematizar os mecanismos responsáveis pelo aparecimento de ascite, exemplifican- do, com pelo menos duas doenças, um dos mecanismos apontados}

A ascite pode ser definida como o acúmulo de líquido livre no interior da cavidade abdominal. As causas da ascite vêm a seguir.

1) Doenças no peritônio: tuberculose, histoplasmose, implantes de células malignas.

2) Doenças no fígado: a cirrose hepática é a causa mais comum.

3) Congestão hepática: insuficiência cardíaca, pericardite constrictiva, síndrome de Budd-Chiari.

4) Extravasamento de suco pancreático (ascite pancreática): lesão de ducto pancreático, ruptura de pseudocisto pancreático.

5) Doenças que acometem gânglios linfáticos (ascite quilosa): linfomas, tuberculose.

6) Hipoproteinemia: síndrome nefrótica, desnutrição.

Os mecanismos de formação de ascite são diversos, na dependência da doença que desencadeou o processo.

As doenças envolvendo peritônio podem causar ascite por aumento da permeabilidade dos capilares peritoneais, provocando exsudação. $\mathrm{Na}$ insuficiência cardíaca e na síndrome de Budd-Chiari (obstrução das veias supra-hepáticas), observa-se congestão hepática com aumento da pressão sinusoidal. A ascite pancreática ocorre por derramamento de suco pancreático na cavidade peritoneal, podendo provocar peritonite química. As doenças que envolvem os gânglios linfáticos, abdominais podem causar ascite de alto conteúdo linfático (aspecto leitoso, denominada ascite quilosa). Na hipoproteinemia, a diminuição da pressão oncótica é responsável pela ruptura do balanço entre a pressão hidrostática e a pressão oncótica nos vasos, causando o extravasamento de líquidos para a cavidade abdominal.

A cirrose hepática é responsável por mais de $60 \%$ dos casos de ascite. Os mecanismos fisiopatológicos da formação de ascite, na cirrose, são complexos. O aumento da pressão hidrostática, nos vasos esplâncnicos, associado à diminuição da pressão oncótica, secundária à hipoalbuminemia, resulta em extravasamento do fluido para a cavidade peritoneal. Uma vez ultrapassada a capacidade de reabsorção do fluido pelos vasos linfáticos, forma-se a ascite.

A pressão portal pode aumentar, se houver aumento do fluxo sangüíneo portal ou aumento da resistência vascular ou de ambos. O aumento da resistência, na cirrose, é de localização intra-hepática e pode ser sinusoidal, pré-sinusoidal e pós-sinunoidal. É comum que o aumento da resistência ocorra em várias áreas, além do que, conforme a doença progride, novos sítios podem ser envolvidos. Reconhece-se o importante papel da alteração estrutural da microcirculação hepática (fibrose, capilarização dos sinusóides e nódulos de regeneração) como o mecanismo mais importante para o aumento da resistência vascular na cirrose, processo esse que, na maioria das vezes, é considerado irreversível. Recentemente, tem sido demonstrado que, em associação com o componente mecânico da resistência vascular hepática, existe um componente dinâmico, que se deve ao aumento do tônus vascular. As substâncias vasoativas, produzidas pelo endotélio vascular, como vasodilatadores (prostaciclinas e óxido nítrico) e vasoconstrictores (endotelinas e prostanóides), agem de forma parácrina na musculatura lisa de vasos e nas ativadas células estrelares e modulam o tônus vascular, normal, o qual é mantido pelo balanço entre substâncias vasodilatadoras e vasoconstrictoras. A perturbação desse balanço leva a anormalidades no tônus vascular.

O aumento do fluxo sangüíneo portal é conseqüente à vasodilatação em órgãos esplâncnicos, que drenam o sangue para a veia porta. A vasodilatação também ocorre na circulação sistêmica. Ressalta-se que a vasodilatação é o evento iniciador da circulação hiperdinâmica, que é observada em estágios avançados de hipertensão portal. A vasodilatação esplâncnica e periférica atua como ativador de sistemas neurohumorais, provocando retenção de sódio e ascite. A circulação hiperdinâmica é caracterizada por diminuição da resistência vascular, periférica, diminuição da pressão arterial, média, expansão do volume plasmático, aumento do fluxo sangüíneo, esplâncnico e aumento do débito cardíaco. 
Os fatores envolvidos na determinação do aumento do fluxo sangüíneo não estão totalmente esclarecidos. Três mecanismos podem contribuir para a vasodilatação periférica, como aumento dos vasodilatadores circulantes (glucagon), aumento da produção endotelial de vasodilatadores locais (NO, prostaglandinas) e diminuição da resposta a vasoconstrictores endógenos, este último mecanismo, provavelmente, sendo efeito dos dois primeiros.

\section{8- Determinar, pelas técnicas da percussão e palpação, a ocorrência de hepatomegalia}

A medida da distância da qual o fígado é palpado abaixo do rebordo costal, na linha hemiclavicular, pode não ser um método seguro para que se conclua pelo diagnóstico de hepatomegalia, o que é devido ao fato de que o órgão pode estar rebaixado de sua posição normal (exemplo, tórax enfisematoso). Deve-se ter presente, também, que, normalmente, o fígado pode ser palpado a um ou dois centímetros abaixo do rebordo costal. Para determinar-se a presença de hepatomegalia, é necessário que se estabeleçam dois pontos de referência: o primeiro, correspondente à parte mais alta do órgão, determinado pela percussão; o segundo, representado pela borda inferior, obtido pela palpação. A percussão revela que, em geral, a parte superior do fígado coloca-se na altura do sexto espaço intercostal ou um pouco mais acima. A estimativa do limite inferior do fígado, pela percussão, é, entretanto, difícil e sujeita a muitos erros.

Medindo, com uma fita métrica ou uma régua, a distância entre o limite superior e o inferior, pode-se dizer que o tamanho do fígado de um indivíduo adulto pode ser considerado normal, se não ultrapassar $5 \mathrm{~cm}$ na linha mediana, $10 \mathrm{~cm}$ na linha medioclavicular e 13 $\mathrm{cm}$ na linha axilar, anterior. São valores válidos, quando o limite superior foi determinado pela ocorrência de macicez. Se o foi pela submacicez, pode-se considerar $1 \mathrm{a} 2 \mathrm{~cm}$ a mais nas três linhas verticais, consideradas. É interessante fazer, pelo menos, as duas primeiras medidas mencionadas, pois, estar-se-á fazendo uma avaliação em separado do lobo direito e do esquerdo do fígado.

\section{9 - Esquematizar os mecanismos responsáveis pelo aumento do fígado, exemplificando, com pelo menos duas doenças, um dos me- canismos apontados}

$\mathrm{O}$ volume do fígado pode aumentar em diferentes condições, tais como, congestão, aumento do número de células inflamatórias, depósito de tecido fibroso, infiltração por células neoplásicas, tumores primários do fígado, cistos, abscessos ou ainda pelo aumento do volume das células hepáticas ou das células de Kupffer por depósitos de ferro, gorduras, cobre, glicogênio ou amilóide. Algumas das doenças que cursam com aumento de volume do fígado estão listadas a seguir.

1) Congestão: insuficiência ventricular, direita; pericardite constrictiva; síndrome de Budd-Chiari.

2) Processos infecciosos: abscessos bacterianos, infecções virais (incluindo hepatites agudas e crônicas), mononucleose.

3) Doenças parasitárias:abscesso amebiano, esquitosomose, hidatidose, calazar, malária.

4) Doenças metabólicas: hemocromatose, amiloidose, doença de Wilson, glicogenoses, esteatose.

5) Neoplasias: carcinoma hepatocelular, metástases, hemangiomas, linfomas.

6) Outras: colestases, hepatite auto-imune, cirroses de diferentes etiologias, hepatites medicamentosas, fibrose hepática congênita.

\section{0 - Efetuar a palpação do fígado, descrevendo suas características quanto à consistência, espessura da borda, sensibilidade, estado da superfície e pulsatilidade}

A palpação do fígado é importante para se saber o tamanho do órgão e algumas características que podem ser avaliadas pelo sentido do tacto e que podem ser de muita relevância para o diagnóstico das hepatopatias. Três regras técnicas devem ser observadas na palpação do fígado: o paciente deve estar com o abdômen o mais relaxado possível, não se deve aprofundar excessivamente a mão e a manobra palpatória deve ser regida pelos movimentos respiratórios. Quanto a esta última regra, a boa técnica consiste em preparar a mão durante a expiração e palpar, quando a descida do diafragma, durante a inspiração, move o órgão para baixo. Muitas vezes, é contraproducente pedir ao paciente que faça respiração abdominal e, pior ainda, é solicitar, como treinamento, que levante a mão do examinador colocada sobre o abdômen; em geral, isso resulta em aumento da tensão das paredes durante a inspiração. O melhor é o médico mostrar, com sua própria respiração, como ele quer que a respiração seja feita pelo paciente. Tanto faz respirar pela boca ou pelo nariz, o importante é que o paciente o faça com a menor possível tensão da musculatura 
abdominal. Durante a palpação superficial, muito freqüentemente, o examinador já perceberá que o fígado está aumentado.

O primeiro e o mais simples dos métodos para palpar o fígado é o seguinte: paciente em decúbito dorsal, respirando adequadamente, médico em pé, à sua direita. A mão esquerda do médico será colocada na região costolombar, fazendo certa compressão no sentido póstero-anterior, com o objetivo de melhor expor o fígado à palpação. A mão direita, espalmada, será colocada na face anterior, em posição abaixo do local onde se presume palpar o rebordo hepático. Será levemente aprofundada durante uma expiração e, na inspiração seguinte, realizará leve movimento em direção à reborda hepática e também para o alto, com o fito de sentir o toque do órgão ou, melhor ainda, seu ressalto junto às pontas dos dedos indicador e médio, da mão direita.

O segundo método é realizado da seguinte maneira: o médico coloca-se junto ao hipocôndrio direito, com seu dorso voltado para a face do paciente. Aplica suas duas mãos, curvadas em garra sobre a zona a palpar. Durante a inspiração o que se tem a fazer é, simplesmente, esperar que a reborda hepática resvale na superfície palmar dos quatro últimos dedos, dispostos em garra. A manobra pode, também, ser executada com apenas uma das mãos, seus dedos colocados, igualmente, em garra. Este segundo método é especialmente recomendado, quando a resistência abdominal está aumentada e para rebordos não muito abaixo do rebordo costal.

Um terceiro método pode ser mencionado, o do rechaço hepático. Ele é aplicável quando, entre o fígado aumentado e a parede, se interpõe um volume líquido, dificultando a palpação por outro método. É realizado da seguinte maneira: à direita do paciente, com os dedos da mão direita reunidos, aplicam-se pequenos golpes na parede anterior do abdômen a fim de tocar a superfície do fígado e repeli-lo para regiões mais profundas, mantendo-se a mão no local, a fim de perceber o contra-golpe do órgão ao retornar à posição inicial. Quando a manobra for positiva, pode-se concluir pela existência de ascite e determinar a distância máxima que se pode perceber o fígado em relação ao rebordo direito.

As características que devem ser investigadas no fígado palpado são as relatadas a seguir.

Estado da borda inferior - normalmente, a borda do fígado tem estrutura fina. Em situações patológicas, quando o órgão cresce (exemplos, congestão passiva na insuficiência cardíaca, esteatose e cirrose hepática), a configuração da borda torna-se arredondada e grossa, habitualmente designada como romba.

Superfície - é regularmente lisa. Na presença de alterações patológicas, pode-se identificar superfície irregular, formada por finas granulações (exemplo, cirrose hepática) ou saliências ou nodosidades maiores (exemplos, câncer, cirrose, cistos hidáticos)

Consistência $-o$ fígado normal apresenta consistência firme, com certa elasticidade, que, habitualmente, é referida como "parenquimatosa". Apresenta-se mole na esteatose e duro na cirrose, na congestão crônica e no câncer. Em cistos hidáticos, calcificados o fígado pode mostrar consistência pétrea.

Sensibilidade - a dor despertada pela palpação pode ser difusa ou localizada. A dor difusa ocorre em processos patológicos, inflamatórios, difusos, agudos ou crônicos, do fígado (exemplos, hepatites agudas e crônicas). A dor dos processos localizados é despertada pela pressão (ou leve percussão) sobre o local e costuma ser aguda e intensa. A provocação de dor aguda pela percussão leve de qualquer ponto da área de projeção do fígado é conhecida como sinal de Torres Homem, médico brasileiro do século XIX, e descrita no abscesso amebiano do fígado.

Pulsatilidade - o fígado aumentado pode mover-se discretamente a cada pulsação arterial. O movimento pode ser decorrente da transmissão pelo contacto direto com a aorta abdominal. A pulsação verdadeira é percebida pela expansão do volume do órgão durante a sístole e sua subseqüente redução na diástole. É, portanto, uma pulsação expansível, percebida quando se colocam as mãos em posições apostas sobre o órgão, verificando se elas, alternativamente, divergem e convergem. É observado em casos de regurgitação tricúspide, grave; Nesta situação patológica, o fígado recebe, durante a sístole, um volume retrógrado de sangue venoso, dado pela regurgitação tricúspide e, ao mesmo tempo, o sangue arterial, vindo da artéria hepática. O pulso hepático é o resultado do encontro simultâneo dos dois pulsos.

\section{1- Efetuar a palpação do baço, descrevendo as suas características quanto a tamanho, for- ma, consistência, estado da superfície e sen- sibilidade}

A palpação é o melhor método para a exploração clínica do baço. O baço de tamanho e de localização normal não é palpável. Quando está grandemente aumentado, pode ser palpado facilmente e suas 
características estruturais, identificadas sem dificuldade. Quando está moderadamente aumentado, pode ser palpado apenas durante a inspiração. Para ser palpável, o baço deve alcançar o dobro do seu tamanho normal. $\mathrm{O}$ aumento do baço costuma determinar submacicez ou macicez em áreas entre a linha axilar anterior e a posterior, entre o nono e o décimo-primeiro intercostos esquerdos, área que não é o espaço de Traube, como aparece em alguns livros de semiologia.

Dois fatores facilitam a palpação do baço, pouco ou moderadamente aumentado, que se esconde sob o gradeado costal no hipocôndrio esquerdo: o movimento de decúbito (quando é assumido o decúbito lateral, direito ou a posição de Schuster) e o movimento de descida durante a inspiração (sobe durante a expiração). Assim, a palpação do baço é facilitada, quando feita durante a inspiração e na posição facilitadora de sua descida.

Dois métodos palpatórios são, habitualmente, utilizados para a palpação do baço: um que é feito com o paciente em decúbito dorsal e outro com o paciente na posição intermediária de Schuster.

1) Primeiro método: no transcurso do exame do abdômen, é o primeiro método a ser executado na palpação do baço. O paciente permanece em decúbito dorsal, mantendo a musculatura abdominal o mais relaxada possível. O médico posta-se à direita do paciente. Pela palpação superficial, anteriormente feita, o médico já pode ter percebido baço facilmente identificável. É muito importante a observância dos movimentos respiratórios para a palpação do baço, assim como o é para a palpação do fígado. A penetração da mão, na região onde se situa o órgão, é feita de maneira lenta, sem forçar, durante as fases expiratórias. Não há necessidade de aprofundar muito a mão, uma vez que o bordo esplênico coloca-se logo abaixo da parede abdominal. Estando à direita do paciente, é mais cômodo que o médico use sua mão direita para palpar o baço. Os canhotos, mesmo colocando-se à direita do paciente, costumam adaptar-se e palpar o baço com a mão esquerda. Com a mão espalmada sobre a região onde se presume estar o baço, formando com a linha mediana um ângulo de cerca de $45^{\circ}$, o médico deve pedir ao paciente que faça lentos movimentos respiratórios e um pouco mais profundos do que o habitual. A mão deve ser mantida em posição de palpar, mantendo uma certa resistência à descida do baço, que ocorre du- rante a inspiração. Durante esse movimento respiratório, o bordo esplênico, que vem descendo, deve se encontrar com as pontas dos dedos indicador e médio e com a borda radial do indicador, tocandoos ou provocando um ressalto.

2) Segundo método: o baço é palpado, estando o paciente na posição intermediária de Schuster: posição intermediária entre o decúbito dorsal e o decúbito lateral, direito. Para que o paciente fique bem acomodado nessa posição e não contraia sua musculatura abdominal, sua perna esquerda é fletida e o joelho esquerdo faz ponto de apoio sobre a mesa de exame. O paciente, portanto, mantém-se equilibrado e relaxado na posição intermediária, apoiando-se na base formada pelo tronco, perna direita estendida e perna esquerda fletida com o joelho tocando a mesa de exame. Portando, não há necessidade de o paciente apoiar-se no corpo do médico, sentado na cama do lado esquerdo do paciente. Além do mais, os preceitos de prevenção de infecção hospitalar rezam que o médico deve evitar sentar-se na cama do paciente. A posição intermediária de Schuster induz o movimento do baço em direção ao rebordo costal, favorecendo a palpação. O médico pode colocar-se à direita ou à esquerda do paciente.

Colocando-se, em pé, à direita, a mão direita com sua palma voltada para cima e levemente encurvada, posiciona-se na área onde se presume estar a borda esplênica e aprofunda-se de maneira semelhante à anteriormente descrita. $\mathrm{O}$ médico deve dar ao paciente as mesmas instruções relativas à respiração, mencionadas na descrição do primeiro método. Estando em posição, a borda esplênica será percebida pela face palmar de um ou mais dos quatro últimos dedos. Como é interessante obter amplas inspirações para se proceder à palpação do baço, o examinador pode colocar sua mão esquerda sobre o gradeado costal esquerdo do paciente, e exercer manobra de oposição à sua expansão, travando seus movimentos. Presume-se que, com isso, o paciente passe a ter, predominantemente, respiração diafragmática, esquerda, favorecendo a palpação do baço.

Posicionando-se à esquerda do paciente, a mão direita em garra procura sentir o pólo inferior, esplênico, abaixo ou junto ao rebordo costal, esquerdo. Além de ser efetuado na posição intermediária de Schuster, o método pode ser aplicado com o paciente em decúbito lateral, direito. Essa forma de palpar, com o médico à esquerda do paciente, é conhecida, também, como 
processo de Mathieu-Cardarelli, podendo ser considerada um terceiro método de palpação do baço.

Das características palpatórias do baço, a mais importante é o tamanho. A referência ao tamanho é inferida pela distância que vai do rebordo costal, esquerdo ao ponto extremo de palpação do órgão, na linha hemiclavicular, esquerda. Infecções agudas conferem ao baço consistência mole, com bordos rombos; as esplenomegalias crônicas costumam ser duras e ter bordos cortantes. O baço será doloroso, quando um processo inflamatório atinge sua cápsula ou na vigência de infarto esplênico.

O elemento palpatório para diferenciar o baço de uma massa no quadrante superior, esquerdo (exemplo, tumor gástrico, rim esquerdo) é o reconhecimento das duas ou três chanfraduras no seu bordo interno, desde que a forma normal do órgão seja conservada. Na distinção entre esplenomegalia e massas no hipocôndrio ou quadrante superior, esquerdo pode ser útil à percussão; na esplenomegalia, a área de percussão será maciça ou submaciça, o que pode não ocorrer no outro caso.

É preciso estar atento para evitar um erro não raro: tomar como baço a palpação da última costela flutuante.

\section{2- Esquematizar os mecanismos responsáveis pelo aumento do volume do baço, exempli- ficando, com pelo menos duas doenças, cada um dos mecanismos apontados}

Para simplificar, pode-se afirmar que há dois mecanismos básicos, que produzem esplenomegalia. Ela pode ser congestiva, quando o crescimento é forçado por congestão de sangue venoso, ou proliferativa, quando o aumento do volume é dado por crescimento do contingente celular do órgão. $O$ aumento do órgão pode ser difuso, com manutenção de sua forma normal, ou decorrente de comprometimento focal (exemplos, cistos, hemangiomas).

As principais causas de esplenomegalia, segundo a natureza do processo patológico envolvido, com alguns exemplos representativos de cada uma das causas são apresentadas a seguir.

\section{Inflamatórias}

a) agudas: septicemia, febre tifóide, mononucleose infecciosa, etc

b) subagudas: endocardite bacteriana, subaguda

c) crônicas: leishmaniose, malária, tuberculose, lúpus eritematoso, cistos hidáticos

\section{Congestivas}

a) hipertensão portal por cirrose hepática, esquistossomose

b) trombose da veia porta, da veia esplênica

\section{Hiperplásticas}

a) anemias hemolíticas

b) leucemias

c) policitemia vera

d) púrpura trombocitopênica

\section{Infiltrativas}

a) doença de Gaucher

b) doença de Niemann-Pick

c) amiloidose

\section{Neoplásicas}

a) hemangiomas

b) linfossarcoma

c) doença de Hodgkin

Além do exame clínico do órgão, deverá haver dados obtidos na anamnese, no exame físico de outros órgãos e sistemas e exames subsidiários, que indicarão o diagnóstico definitivo de uma esplenomegalia.

\section{3 - Efetuar a palpação da vesícula biliar e indi- car seu significado clínico}

A vesícula biliar, normal não é palpável; somente o será, se apresentar aumento em seu volume, além de tensão aumentada de suas paredes ou aumento de pressão em seu interior, pela dificuldade de esvaziamento de seu conteúdo. $\mathrm{O}$ aumento da vesícula biliar e as mencionadas manifestações correlatas decorrem de obstrução do ducto cístico ou do colédoco.

Quando a obstrução está no ducto cístico, não há icterícia. A obstrução do cístico pode ser devida a cálculos, ou por processo inflamatório, que a excluem da árvore biliar. Ela se distende devido ao acúmulo de sua própria secreção e constitui o que é denominado de vesícula hidrópica.

Quando é o colédoco o canal biliar obstruído, há icterícia do tipo obstrutivo. A obstrução do colédoco, que, geralmente, causa distensão da vesícula biliar, é a provocada por tumores do pâncreas ou das próprias vias biliares, pois a vesícula não calculosa apresenta elasticidade conservada. A obstrução por cálculos, em geral, não causa dilatação da vesícula, porque o paciente já apresenta uma vesícula doente (colecistite crônica, calculosa) e já fibrosada ou esclerosada. Entretanto, há exceções. 
Na vigência de icterícia obstrutiva, a presença de vesícula palpável é claro indicador do diagnóstico topográfico da doença: a obstrução situa-se fora do fígado (icterícia obstrutiva extra-hepática), no colédoco ou na sua desembocadura no duodeno; nessa situação, a principal hipótese diagnóstica é de obstrução por neoplasia, a não ser que exista quadro clínico acompanhante, muito sugestivo de doença calculosa. De qualquer forma, a presença de icterícia obstrutiva com vesícula palpável indica que a resolução terapêutica do caso é de competência cirúrgica.

A vesícula biliar é palpável no ponto em que a margem inferior do fígado cruza a borda externa do músculo reto, anterior, direito, do abdômen.

Aumentada e tensa será palpada como uma formação arredondada, de superfície lisa e consistência elástica, eventualmente com pequena mobilidade laterolateral, que se destaca da borda inferior do fígado, fazendo corpo com ele. Às vezes, a vesícula aumentada pode provocar pequeno abaulamento da parede abdominal. A palpação pode ser dificultada por dor local.

A vesícula biliar pode ser palpada pelo método de Mathieu, semelhante ao descrito para a palpação do fígado: paciente em decúbito dorsal; médico ao seu lado direito, dando-lhe as costas; uma ou duas mãos aplicadas no hipocôndrio direito, com os dedos recurvados "em gancho", como para sentir a borda hepática. A palpação da vesícula ocorrerá durante uma inspiração de profundidade, adequada para cada paciente.

O outro método consiste em aplicar a mão direita, levemente inclinada e espalmada sobre o hipocôndrio direito, junto à borda hepática, estando-se em pé ao lado direito do paciente. Durante uma inspiração, as extremidades dos três dedos centrais poderão identificar a vesícula biliar.

Um processo palpatório interessante é o de se fazer movimentos circulares, com discreta compressão, na área vesicular, com os três dedos centrais da mão direita. Com tal método, tem-se conseguido palpar muitas vesículas e ele é aplicável, principalmente, nos casos em que há dor local.

\section{4 - Testar a sensibilidade dos rins pela percus- são dos ângulos costovertebrais, com a bor- da cubital da mão (pesquisa do sinal de Giordano)}

Existem pontos, na região lombar, cuja palpação pode despertar dor, na vigência de afecções renais e uretéricas (exemplos, nefrite, pielonefrites agudas, tuberculose renal). As dores provocadas, muitas vezes, coincidem com dores espontâneas dos pacientes. São dois os pontos: o lombar costovertebral (no vértice do ângulo formado pela última costela e a coluna vertebral) e o lombar costomuscular (no vértice do ângulo formado pela massa muscular sacrolombar e pela última costela). A pesquisa de dor, nesses pontos, é feita mediante sua compressão com um único dedo.

Tanto nas doenças acima referidas, como no câncer e na litíase renal, a percussão da região lombar (o paciente sentado na cama, com o dorso descoberto e o examinador, desse mesmo lado) mediante golpes secos com a borda cubital de uma das mãos (manobra de Giordano) pode despertar uma intensa dor aguda. Aconselha-se que a referida manobra seja realizada em diferentes alturas das regiões lombares, direita e esquerda. A percussão deve iniciar-se com manobras leves, aumentando-se gradualmente, porque não se pode prever a intensidade da dor que elas poderão desencadear. Quando a manobra de Giordano produz a dor aguda e intensa, diz-se, habitualmente, que o paciente apresenta o sinal de Giordano positivo, entretanto, nos livros de semiologia consultados, não se encontra tal designação. Deve-se sempre anotar se a positividade da manobra (produção de dor) foi à direita, à esquerda ou em ambas as regiões.

\section{5- Estabelecer o significado clínico da positi- vidade do sinal de Giordano, diferenciando de outras causas de dor à percussão das re- giões lombares}

A positividade da manobra de Giordano não indica, de forma decisiva, uma afecção renal ou pielocalicial. $\mathrm{O}$ abalo ou a trepidação produzida pelo golpe feito com a borda cubital da mão, na região lombar, pode despertar dor em qualquer órgão ou estrutura subjacente, se estiver com algum processo inflamatório (apendicite, hepatite aguda, afecção osteomuscular). São os dados colhidos na anamnese, ao lado de outros achados do exame físico, que levantarão a hipótese diagnóstica mais plausível. Além disso, exames subsidiários, pedidos de acordo com as sugestões ditadas pela meticulosa observação clínica, serão importantes para o diagnóstico definitivo. $\mathrm{O}$ sinal de Giordano é um típico exemplo de achado de significado inespecífico do exame físico. Seu valor semiológico está relacionado com os demais dados clínicos, apresentados pelos pacientes. 


\section{6- Efetuar a ausculta sistematizada do abdômen, identificando os ruídos hidroaéreos e des- crevendo suas características quanto a fre- qüência, intensidade e timbre}

A ausculta é a parte do exame físico do abdômen que se segue à inspeção e precede a palpação. Esta não é uma seqüência obrigatória, mas é recomendada por alguns semiologistas, com o argumento de que o prévio manuseio do abdômen alteraria a ausculta.

Nessa parte do exame, descrevem-se os sinais acústicos, percebidos por intermédio do estetoscópio, ouvindo-se os quatro quadrantes do abdômen e, especialmente, sua área central, durante dois a três minutos. Os ruídos audíveis, dependentes do tubo gastrointestinal são conhecidos com o nome genérico de hidroaéreos.

Os ruídos hidroaéreos são audíveis com o auxílio do estetoscópio, em condições normais, em localização variável e em momentos imprevisíveis, produzidos pela movimentação normal do conteúdo gastrointestinal líquidogasoso. Em condições patológicas, podem estar com intensidade aumentada (exemplos, nas diarréias, na presença de sangue na luz de alças intestinais, em decorrência de hemorragias digestivas, altas, na obstrução intestinal) ou reduzida ou abolida (exemplo, íleo paralítico situação em que há abolição ou grande redução dos movimentos intestinais, como no pós-operatório de cirurgias abdominais). Uma variação do timbre dos ruídos hidroaéreos, o timbre metálico, é observada nos casos de obstrução do intestino delgado.

\section{7- Discutir os possíveis mecanismos determi- nantes de anormalidades da ausculta abdo- minal}

As variações, para mais ou para menos, do turbilhonamento do conteúdo líquidogasoso, dos intestinos acompanham alterações da atividade motora do órgão. Quando a atividade motora está aumentada, em decorrência de intensa atividade propulsiva ou quando há um peristaltismo de luta para vencer uma semi-oclusão (exemplos citados no item 12), ocorre aumento da freqüência e da intensidade dos ruídos hidroaéreos (ruídos hiperativos). Quando a atividade motora está diminuída ou abolida (exemplos citados no item 12), há redução ou até ausência ("silêncio abdominal") dos ruídos hidroaéreos.

\section{8- Identificar a presença de sopros e seu signi- ficado}

Além dos ruídos intestinais, ou seja, aqueles dependentes da movimentação da mistura líquidogasosa, a ausculta do abdômen pode revelar ruídos vasculares, atritos e ruídos obstétricos.

Os ruídos vasculares incluem os sopros que podem ser sistólicos ou contínuos.

Os sopros sistólicos são originários de artérias abdominais, que apresentam alterações de seu fluxo a ponto de produzir o ruído característico.

Os sopros sistólicos abdominais mais freqüentes são os produzidos pelo aneurísma da aorta abdominal ou pelas artérias hepática e esplênica.

No aneurisma da aorta, o turbilhonamento do sangue ocorre na parte em que a artéria de calibre normal se abre na parte bojuda. Há situações, em que, nesse mesmo local, é gerado ruído semelhante ao de uma bulha cardíaca. Os sopros do aneurisma da aorta são audíveis na linha mediana do abdômen, sem se fazer demasiada pressão com o estetoscópio.

O sopro hepático pode ser audível em qualquer ponto da área de projeção do fígado, na superfície do abdômen; indica fluxo arterial anormal, no local, como pode acontecer no aneurisma da artéria hepática, na cirrose e no carcinoma hepatocelular.

Os sopros esplênicos são audíveis no hipocôndrio esquerdo, em geral, entre as linhas hemiclavicular e axilar, anterior, esquerdas. Podem ser encontrados no baço de pacientes com malária, leucemia, cirrose hepática ou tumores esplênicos.

Os sopros contínuos são venosos e o exemplo mais marcante é o audível sobre a circulação colateral, periumbilical, decorrente de hipertensão portal. Decorre do hiperfluxo na veia umbilical, recanalizada que, além do sopro, pode produzir frêmito no local (síndrome de Cruveillier-Baumgarten).

Os atritos observados no abdômen são raros. Decorrem da movimentação do órgão (em geral, fígado ou baço, mas, também, com vísceras ocas) junto à parede abdominal, em ponto onde um processo inflamatório determinou alterações na textura das respectivas superfícies, tornando-as ásperas. Os processos peritoneais, crônicos representam as principais causas dessa anormalidade semiológica. A movimentação referida é aquela determinada pelos movimentos respiratórios.

Dos ruídos obstétricos, menciona-se o sopro uterino ou placentário, doce, suave, inconstante, de sede variável, presente depois do $3^{\circ}$ ou $4^{\circ}$ mês de gestação. De origem fetal, menciona-se o batimento cardíaco, caracterizado pela sua alta freqüência (140 batimentos/min). 
MENEGHELLI UG \& MARTINELLI ALC. Principles of semiotechnic and interpretation of the abdomen clinical examination. Medicina, Ribeirão Preto, 37: 267-285, july/dec. 2004.

ABSTRACT: The aim of this article was to provide medical students with basic knowledgement about how to perform and interpretate the clinical examination of the abdomen. In order to reach this aim we discussed 28 itens proposed by the coordination of the course of semiology of the Department of Medicine - School of Medicine of Ribeirão Preto, São Paulo University. The article comprehend the main topics of inspection, auscultation, palpation and percussion of the abdomen.

UNITERMS: Clinical Examination. Semiology. Inspection. Auscultation. Palpation. Percussion. Abdomen.

\section{REFERÊNCIAS BIBLIOGRÁFICAS CONSULTADAS E RECOMENDADAS}

1 - PORTO CC. Exame clínico. $2^{a}$ ed, Guanabara Koogan, Rio de Janeiro, 1992.

\section{2 - SURÓS J. Semiologia medica y tecnica exploratoria. $5^{\mathrm{a}}$ ed, Salvat Editores, Barcelona, Espanha, 1972.}

3 - DEGOWIN RL - Diagnóstico clínico. $5^{\mathrm{a}}$ ed, Medsi, Rio de Janeiro, 1990.

4 - RAMOS J \& CORREIA NETO A. Propedêutica do abdômen. Instituto Progresso Editorial, São Paulo, 1948.

5 - ROMEIRO JV. Semiologia médica. $11^{\mathrm{a}}$ ed, Guanabara Koogan, Rio de Janeiro, 1968. Tomo II. 